DOI: 10.20472/IAC.2018.042.021

\author{
PAUL IGWE \\ University of Lincoln, United Kingdom
}

CHIOMA VIVIENNE NWOKORO

Eastern Palm University, Nigeria

\title{
OPEN INNOVATION SYSTEM AND ENTREPRENEURSHIP: A CASE STUDY OF THE OFFSHORE RENEWABLE ENERGY
}

\begin{abstract}
:
This article examines the innovation in the offshore renewable energy (ORE) industry using Open Innovation System (OIS), platforms and network perspective. Despite the benefits of ORE, Operation and Maintenance (O\&M) costs account for up to one-third of total wind energy project lifecycle expenditure requiring relationships with multiple external partners to improve the supply chain and O\&M activities. Therefore, management of the O\&M activities of the supply chain and logistics has become an excellent place to drive efficiency and reduce cost thereby creating innovative products and services, business clusters and job opportunities. Findings show how strategic resources help offshore companies to reduce cost and achieve environmental, economic and social benefit derived from ORE. The OIS is used to explain the importance of new resources in technology, knowledge sharing and relationships, and stresses the role of stakeholders in addressing the challenges. The limitation of this study is related to reliance on secondary data. However, it provided an opportunity to elaborate on OIS theory and reinforces the importance of knowledge sharing, collaboration and network advantage. Overall, this provided insights into the constituent resources needed for successful OIS, regional entrepreneurship and helps move renewable energy research from a technological advancement challenges to a problem of strategic resources and relational capabilities.
\end{abstract}

\section{Keywords:}

Open Innovation System, Regional Entrepreneurship, Dynamic Capabilities, Renewable Energy

JEL Classification: Q55, R38, Q28 


\section{Introduction}

This article examines the Open Innovation System (OIS) in the UK in the offshore renewable energy (ORE) projects which have resulted in a hub of activities for big companies, small and medium enterprises. Offshore Wind Farm (OWF) creates a range of economic impacts at different territorial scales and sectors, one of which is the local sector at the regional level (Copena and Simon, 2018). The UK has the biggest ORE projects in Europe and is the primary coordinator of innovation in the renewable energy focusing on maximising environmental, economic and social impact. The massive expansion of ORE projects (e.g. London Array, Dudgeon, Thanet, Walney, Robin Rigg, etc.) across the UK has the potential to generate jobs activities for hundreds of companies. Wind renewable energy replaces the use of fossil fuels and thus reduces emissions of carbon dioxide (Co2) and other types of air pollution. The European Union aims to achieve 20 per cent of energy consumption from renewable sources by 2020 (Bilgili, Yasar and Simsek, 2011). Despite the development of the OWF in many parts of the world, the UK is expected to maintain its leading position in ORE market globally with its Round 3 ORE development programme containing seven OWF with expected overall capacity of $22 \mathrm{GW}$ and with the potential to produce $32 \mathrm{GW}$, which would be almost three times bigger than the 8GW size of all Round 1,2 and their extension projects together (Danilova, Grant and Menachof, 2016).

Innovating firms engage in both technology exploitation and exploration to be effective in the short run and to survive and prosper in the long term (Geerts et al., 2018). There are four types of innovation: Incremental Innovation, Disruptive Innovation, Architectural Innovation and Radical Innovation. Radical innovation is the commercialisation of an entirely novel idea, new to the firm and its markets, and it is the essence of value creation by large firms and entrepreneurial ventures (Colombo et al., 2017). While radical innovation brings huge economic rewards to firms, it is an activity fraught with risk (Colombo et al., 2017). ORE companies engage in radical innovation to provide clean energy, reduce costs and be profitable. Platforms have been described as products or services that function as foundations upon which others - termed complementors - can build complementary products, services, or technologies (Gawer, 2010). A new competition from the ORE is enabling innovative SMEs working in the offshore renewable sector to prove their technology and connect them with investors and potential clients (Catapult, 2018). The UK government in 2016 approved £28 million for innovation in infrastructure systems in the offshore wind sector (offshoreWind.biz, 2016). Leveraging on the investment, many big corporations including Siemens, EDF energy, E. ON, SSE Renewables are pledging long-term commitment to investing in plants, facilities, research \& development and innovation.

Engaging with stakeholders to drive environmental innovation requires three levels of capabilities. According to Watson et al., (2018, p.256), it needs specific operational capabilities, complex first-order dynamic capabilities to manage the engagement, and second-order dynamic capabilities (engagement learning capabilities) to allow 
organisations to co-create value (value framing) and to learn from their engagement (systematized learning). As the UK offshore wind industry moves towards doubling its installed capacity to $30 \mathrm{GW}$ by 2030 , delivering thousands of additional skilled jobs and billions of pounds worth of export opportunities, building a strong UK supply chain to service the industry is vital (Catapult, 2018). Innovation understood as the recombination of existing ideas or the generation of new insights into new processes and products is widely viewed as the primary driver of growth in modern capitalistic economies (Watkins et al., 2015). Open innovation provides opportunities for utilising external as well as internal ideas as inputs to the innovation process (Eckhardt, Ciuchta \& Carpenter, 2018). The UK government position is that ORE represents a unique opportunity for the UK to pursue economic growth through support for high-growth SMEs, increase thousands of highly skilled jobs, increase energy security and vastly reduce carbon emissions (HM Government, 2013). The UK has the biggest offshore wind industry, and OWF locations in the Northeast of England, London, Wales and Scottish coasts has resulted in a hub of activities. As at 2015, about 1,183 offshore wind turbines have been installed in the UK with a capacity of 4,042 megawatts (MW) creating skilled jobs to about 6,830 full-time employees (Igwe and Howell, 2015).

Management of the ORE operations and maintenance (O\&M) activities of the supply chain and logistics is the right place to drive efficiency, reduce cost and create more opportunities. This sector includes activities that lead to the high-level coordination and management such as turbine design and installation, environmental monitoring, electricity sales, ports facilitates, transportation, marketing, administrative and other auxiliary services in the ORE sector. Many supply chain development activities are already underway, with key players in the industry such as Alstom, MHI Vestas, Siemens, A2SEA, Statoil, Vattenfall and Navitus Bay taking part. Many small and medium enterprises (SMEs) outside these companies are taking advantage of the opportunity to develop new product and services to serve the market in the form of new technology. Based on secondary data, this study sets out to explore the following questions:

- What are the key challenges, the barriers or constraints to offshore wind O\&M?

- How are offshore wind energy challenges being addressed with new solutions and innovation?

- What are the roles of major stakeholders and platforms for entrepreneurship and value creation?

Research in economic geography has paid increasing attention to regional innovation systems (RISs) as a potential vehicle for growth and development (Rypestøl and Aarstad, 2018). There have been calls for more studies to understand the complex micro-foundations of innovation system (Razak and White, 2015; Leven, Holmstrom and Mathiassen, 2014). Therefore, this article focuses on the review of innovation, 
within and across ORE sector and hub of large-scale and SMEs activities in the UK. It explores strategies for the management of the O\&M activities of the supply chain and logistics. It identifies the social and economic benefits derived from the large-scale investment and innovative practices in the sector and the challenges. By exploring these contexts, this research contributes to the literature on innovation in the renewable energy sector. It brings the supply chain perspective into the debate about renewable energy technologies in the context of environmental, economic and social development. In doing so, this study responds to calls for a more integrative approach to research that focuses on ecological and social goals (Govindan et al., 2015), the need to understand value creation (Krikke et al., 2013) and the importance of networks, alliances and partnerships in value creation (Insanic and Gadde, 2014; Matopoulos et al., 2015; Miemczyk, Howard \& Johnsen, 2016). The rest of the paper is structured as follow: The next sections focus on exploring the national, regional and international innovation system, environmental innovation policy, ORE innovation and entrepreneurship. Then, it examines in detail the supply chain and O\&M activities. Finally, it presents theoretical and practical implications, addresses the study's limitations, and suggest avenues for future research.

\section{National, Regional and International Innovation system}

National Innovation Systems (NIS) concept was first proposed by Freeman $(1982,1987)$ as a response to the Washington consensus and the neoclassical approaches to economic growth. There has been a gradual evolution of the study of NIS in the thirty years since it first emerged (Watkins et al., 2015). Since then, innovation remained a critical component for sustained growth and competitive advantage for advanced countries and their firms. Early studies examined the macrostructure of NIS and those factors that characterised economically prosperous nations and mechanisms that lead to different patterns of product and process innovations as well as the breakthrough and diffusion of new technologies and knowledge (Owen-Smith \& Powell, 2004). In the beginning, NIS concept centred on firms (both small and large) as the core institution through which innovations are developed and commercialised (Patel and Pavitt, 1994). In the last two decades, there has been a gradual shift from NIS to regional Innovation system (RIS) (Ornelia, 2015; Guan and Chen, 2012). Some work on innovation systems, such as the concept of the Triple Helix and Quadruple Helix (Etzkowitz, 2003; Etzkowitz and Leydesdorff, 2000), highlights the role of educational establishments in fostering innovation and began to recognise the importance of regional and sectoral innovation systems (Ornelia, 2015; Perkmann and Walsh, 2007). Both the Triple Helix and Quadruple Helix approaches are grounded on the idea that innovation is the outcome of an interactive process involving different spheres of actors, each contributing according to its 'institutional' function in society according to the European Union Committee of the Regions (European Union, 2016). Therefore, the traditional protagonists of the helix stakeholders are University, Industry, and Government and Civil society (Perkmann and Schildt, 2015). More recent work explores International Systems of Innovation (ISI) and the role of multinational corporations (MNCs) in the 
production and diffusion of knowledge and technologies (Malik, 2013; Chaminade, Intarakumnerd and Sapprasert, 2012).

The advance of globalisation has since changed the dynamics and spread of innovation such that MNCs and their associated innovation activities have pushed the mechanisms and direction to cross-border transfer of knowledge and technologies (Zhao and Anand, 2009; Narula, 2014) regarded as International Systems of Innovation (ISI). OIS involves purposive inflows of knowledge to accelerate internal innovation and expand potential markets (Eckhardt et al., 2018). OIS involves not only the work of individual firms but a collective endeavour, requiring diverse stakeholders, resources and expertise. The key stakeholder of the NIS, RIS and ISI identified in the early literature according to Watkins et al., (2015) are (i) governments and related agencies supporting innovation through regulation, standard setting, public-private partnerships, and funding of basic research, (ii) sectors and industries comprised of firms which generate commercial innovation through experimentation, R\&D, and product improvement, (iii) universities which conduct basic research and train a technical and scientific workforce, and (iv) other public and private organisations that engage in education-oriented activities.

Scholars have shown how firm learning often depends on distinct vertical and horizontal network linkages (Morris, Kaplinsky, \& Kaplan, 2012) as well as the ability of local firms to generate new absorptive capacities (Mudambi et al., 2017; McDermott and Corredoira, 2010; Vasudeva and Anand, 2011). These knowledge flows can involve both pecuniary and non-pecuniary mechanisms that interact (Eckhardt et al., 2018). ISI occurs primarily through open discussion and collaboration (Ratten, 2014), by creating open knowledge forums, which support the dynamic interchange of ideas (McLure and Faraj, 2000). Also, networks and collaboration offer firms the opportunity for knowledge acquisition. Knowledge-intensive entrepreneurship (KIE) stands for a socioeconomic phenomenon that drives innovation and economic growth, also functioning as a fundamental source of macroeconomic competitiveness and innovative capabilities (Fischer, Queiroz and Vonortas, 2018). According to Kanter (1994) collaborations are relationship-based (i.e. durable, broad and open-ended). Others maintain that collaborative advantage is the ability to work with network partners to create value and can be sources of inter-organisational competitive advantage. Dyer and Singh (1998) state that there are four sources of network advantage: complementary resources, relation-specific investments, inter-organisational knowledge sharing, and effective governance. Knowledge sharing is often being considered as a crucial element to entrepreneurial learning (Scarmozzino et al., 2017).

Network perspective defines entrepreneurial learning as the building of human and social capital. By forming networks, small firms become stronger through their alliances and networks becomes the 'locus of innovation' (Powell et al., 1996), where collective and social learning takes place (Brown and Duguid 1991). Recent literature on stakeholder engagement has moved away from the idea of making trade-offs between interests, toward exploring the complementarity between stakeholders' resource 
allocations (Henisz, Dorobantu and Nartey, 2014) and the synergistic links between the demands of business and society (O'Riordan and Fairbrass, 2014). During the process of acquisition and transmission of knowledge, entrepreneurs are leveraged by social interactions (Estay et al., 2013) and various forms of participation and engagement (McLureWasko and Faraj, 2005). Through this dynamic process, knowledge is continually being regenerated (McLure and Faraj, 2000). The basic unit of the network is the inter-organisational relationship, which will be varied in nature.

Concerns about the advancement of innovation and knowledge diffusion are at the centre of growing debates at the intersection of economic development of nations and MNE strategy, particularly regarding the role of government in providing the enabling environment for the advancement of innovation. Watkins et al., (2015) observed that while the institutional role of government in providing a stable, supportive, and appropriately competitive environment for innovation is almost overarching in the early literature, how such a situation, through interaction with other institutions, is informed is mostly absent - government as a necessary yet practically passive player in the NIS' dynamics. The absence of absorptive capacity constraints the sequence and nature of learning processes, the shape of technological advances and the core mechanisms of knowledge transfer. Government support provides the platform for innovation in many ways. The concept of a 'platform' has a long-standing history in systems, innovation and technology management literature (Eckhardt, Ciuchta and Carpenter, 2018). Bogers et al., (2017) notes that opening platforms creates opportunities within ecosystems for entities other than the platform leaders and platform can become a venue for entrepreneurial pursuits as opportunities are identified and pursued to create complementary products or services that become part of the platform's 'orchestra'. Orchestra - is equivalent to a platform strategy whereby a keystone player establishes a shared architecture around which the activities of different specialist firms can be orchestrated (Bessant et al., 2014). In the case of offshore wind energy system, the UK government and MNCs are providing the platform required to encourage other medium and small firms to innovate and develop new products and services.

\section{Environmental and Technology Innovation Policy}

Environmental Innovation represents the subset of sustainability-oriented innovation addressing the ecological dimension of sustainability (Adams et al., 2016). It is defined as "the production, assimilation or exploitation of a product, production process, service or management or business method that is novel to the organisation (developing or adopting it) and which results, throughout its life cycle, in a reduction of environmental risk, pollution and other negative impacts of resources use (including energy use) compared to relevant alternatives" (Kemp and Pearson, 2008, p. 7). Geerts et al., (2018) distinguish between technology exploitation and exploration. The earlier refers to the refinement and extension of existing technologies and implies activities like refinement, selection, and implementation. For over 30 years the environmental policy has developed under the assumption that self-interest explains firms' environmental 
behaviour and that the problem of pollution can be rectified by technological fixes (Corral, 2002). The European Commission supports the efforts of regional industry clusters focusing on the development of new environmental technologies, especially in the renewable energy. Environmental Policy and Technological Innovation comprehensively explores the factors which can influence a firm's behavioural approach towards developing clean technologies (Corral, 2002).

Institutional logics explains that organisations are always embedded in specific institutional contexts; these create regularities and stability, and in so doing both constrain and enable organisational activities (Leppäaho and Pajunen, 2018). Hart (1995) suggests "firms that adopt product stewardship strategies will evidence inclusion of external stakeholders in the product development and planning process" (p. 100). This type of innovation is prevalent in rapidly changing business and natural environment contexts, demanding continual resource reconfiguration (Hart, 1995). Environmental innovation poses complex, systemic challenges for how firms engage external stakeholders such as customers, suppliers, government, civil society, and NGOs (Watson et al., 2018). To understand the context of environmental and technological innovation, it is essential to explain why government and firms choose to engage in the first place. While many studies have explored drivers for innovations focusing on legislation or product differentiation (Seitz and Peattie, 2004), understanding the reasons for these actions is still required to appreciate the context fully. Recent studies propose that drivers such as regulations, market demands and potential competitive advantage need to be present (Shi et al., 2012; Rahman and Subramanian, 2012) for companies to invest in innovation elements from products and processes (Hart and Dowell, 2011; Matos and Hall, 2007). The following has been suggested by OECD (2000: 7) as drivers for Sustainable Innovation:

- growing awareness of social values in driving environmental issues,

- the rediscovery of the sense of co-dependency,

- a more determined public with different priorities for innovation and use of technology.

Watkins et al., (2015, p.1409) viewed intermediaries as performing three primary functions. First, these opportunities may represent a technological frontier for the firm which due to its inexperience may require external support. Second, it often involves engagement with multiple stakeholders who are very different from each other in terms of their institutional origins and logic and the ways they assess and value success and failure. Third, it may demand innovation that moves beyond product and process innovation to business model innovation, and as such involves expertise sourced through external and unfamiliar collaboration. Many of today's social and economic developments are a result of technological discoveries and developments in fields such as communications, information processing, health sciences and energy supply. These 
promise smarter, more tailored solutions to the tasks we wish to accomplish. Leading companies have built their approaches to sustainable development upon principles that can be summarised by OECD (2000: 8 ) as follows:

- Ensuring the corporation understands what society expects of it, in return expressing clearly what the firm itself stands for, then reinforcing these values in ways that stretch the organisation and create a spirit of continuous improvement. (Attitude)

- Developing the tools and approaches to improve performance across the social, environmental and economic pillars of sustainable development and incorporating these tools into routine business processes. (Build the capacity to act)

- Setting focused targets and putting in place the means to measure performance and confirm that the goals are being achieved. (Check progress)

\section{ORE Innovation and Entrepreneurship}

Entrepreneurship manifests itself throughout the economy in different forms and with different outcomes, such as the creation of wealth; increasing employment; and tackling of inequalities and environmental issues (OECD, 2016). The UK Government estimates that "in 2020/21, under a strong growth scenario, the sector could deliver in the order of $£ 7$ bn Gross Value Added (GVA) to the UK economy (excluding exports) and support over 30,000 full-time equivalents UK jobs (Igwe and Howell, 2015). The UK government Vision for the UK Offshore Wind Industry states that "Industry and Government work together to build a competitive and innovative UK supply chain that delivers and sustains jobs, exports and economic benefits for the UK, supporting offshore wind as a core and cost-effective part of the UK's long-term electricity mix" (HM Government, 2013: 5). By innovating products, services, production processes, organisational forms, and routines, industries generate economic and social value, thus legitimising their role in the economy and society (Colombo et al., 2017). Innovation for environmental sustainability requires firms to engage with external stakeholders to access expertise, solve complex problems, and gain social legitimacy (Watson et al., 2018). According to HM Government (2013: 5) plan, the UK vision for the ORE is to deliver:

- economic growth creating tens of thousands of long-term UK jobs;

- a transparent and sustainable project pipeline; major manufacturing facilities in the UK;

- the development of a competitive UK-based supply chain and

- a technology cost-competitive with other low carbon technologies. 
Since pioneering the world's first offshore wind farm in 1991, UK ORE has evolved to become a large-scale commercial renewable technology with an important role to play in the Government's long-term plan for a balanced low carbon electricity generation portfolio to help meet UK 2050 carbon targets and enhance the security of supply. The UK National Grid announced in March 2017 that new wind energy provided 35.7 percent of UK electricity, while gas produced 20.3 percent, nuclear supplied 17.6 percent, coal 12.9 percent and imports 6 percent (RenewableUK, 2018). Despite the benefits of offshore wind over onshore projects, O\&M costs account for 14 percent -30 percent of total project lifecycle expenditure as indicated in many studies (for example, Martin et al., 2016). The UK government maintains that there is a need to increase the UK supply chain capabilities that will not only contribute to the economic value of the country but also cost reduction of the ORE (HM Government, 2013). There are many well-known bottlenecks when it comes to producing and installing wind energy technology on an adequate scale to support the green transformation. According to Poulsen and Lema (2017), these include scarcity of sites for new turbine installations; Technologies for dealing with intermittency; Financial resources; Government policies; Subsidies and tariffs; Human capital and skills; Storage capacity for wind energy after production; and Grid expansion and interconnection (p.759).

The landmark success of ORE in the UK is the result of a healthy, vibrant supply chain built with companies such as 3sun, Cwind, Seajacks, Fred Olsen Wind-carrier, etc. (RenewableUK, 2017). Together with long-term price stability and a vast development pipeline, this has helped make the UK one of the most attractive locations in the world to invest in the ORE (Ernst and Young, 2013). Offshore wind farms (OWF) represent a group of wind turbines in the same confined area used for the production of electric power in the open ocean. Table 1 presents estimates of some of the regional jobcreating capacity of UK OWF.

Table 1. Estimates of Jobs creation capacity of OWF

\begin{tabular}{|c|c|}
\hline Projects & Job opportunities \\
\hline Port of Humber & 25,000 advanced engineering jobs predicted. \\
\hline The Port of Grimsby & About 1,000 people employed already in the area. \\
\hline London Array & $\begin{array}{l}\text { Over } 75 \text { organisations and } 6,700 \text { people helped } \\
\text { build the project. About } 76,000 \text { jobs are forecast by } \\
\text { the dawn of the next decade. }\end{array}$ \\
\hline Outer Moray & $\begin{array}{l}\text { Employment for up to } 460 \text { created at the peak of the } \\
\text { project and up to } 580 \text { during the operation. }\end{array}$ \\
\hline Gwynt y Môr & $\begin{array}{l}\text { Over } 150 \text { short-term jobs created during construction } \\
\text { and over O\&M } 100 \text { long-term skilled engineering } \\
\text { jobs. }\end{array}$ \\
\hline
\end{tabular}

Source: Igwe and Howell (2015) 
The major industrial players in the UK OWF developers include ORSTED - Nasdaq Copenhagen, Scottish and Southern Energy (SSE), SSE Renewables E. ON, Centrica, Npower, EDF-EN, Samsung, 2-B Energy and the major turbine manufacturers are Danish manufacturer Vestas, Siemens, Repower and Samsung. ORE stakeholders recognise that stripping costs out of the supply chain will be significant to encourage firms to continue to invest in the sector and promote economies of scale of renewable energy. For this reason, the ORE Cost Reduction Task Force (CRTF, 2012) has recommended that a new project delivery option is known as "alliancing" be used. Alliancing is an arrangement that includes a structure to share risk and reward among multiple contractors and the owner; thus, the financial success of each of the parties are linked to the overall success of the project (Anvuur and Kumaraswamy, 2007). There has been many joint projects and alliances in the ORE which is creating a hub of large, medium and small industries (such as wind farm owners, developers, manufacturers, surveyors, specialist and professional services, and various engineering, monitoring, electrical and manufacturing industries), each requiring their own technical specifications and accreditations.

\section{Operations and Maintenance (O\&M) activities}

Management of the O\&M activities of the supply chain and logistics are the right place to drive efficiency and reduce cost through innovation (EWEA, 2015). The relationship between sea depth and costs has been one of the major setbacks of the development of OWF deep-water projects, despite the extra productivity benefits that are often achieved from a distance to shore (due to higher wind speeds). As more offshore wind projects are built, further from shore, accessing the turbines to carry out maintenance provides new technical and logistical challenges. More so, OWF turbines suffer from high failure rates due to weather and other sea conditions. Some of the offshore wind elements where technological innovation has been the focus include turbines design and foundation types, weather and sea conditions monitoring systems and operations and maintenance support services (such as ports facilities and design, vessels/ boat design, helicopter and drone operations, etc.). Li et al. (2015a \& b) summarised the factors affecting ORE availability as shown in Figure 1 and explored in the next subsections. 
Figure 1. Innovation and Optimization of OWF Operations and Maintenance

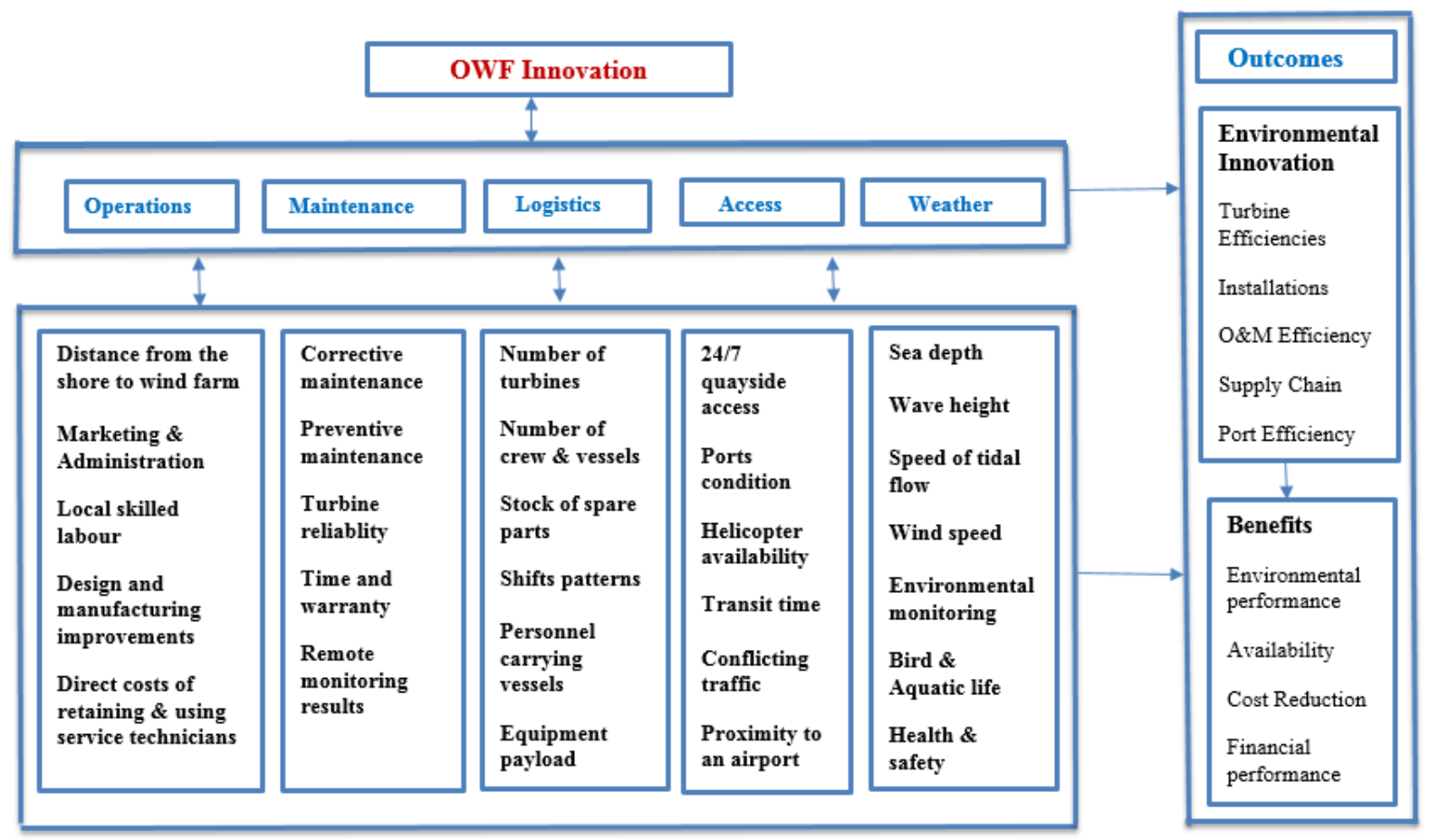

Source: Li et al., (2015a\&b)

\section{Offshore wind Installation challenges}

Typically, offshore wind farms currently faceless socio-environmental barriers, which reduces design constraints and facilitates their implementation (Dedecca, Hakvoort and Ortt, 2016). However, the installation of offshore wind energy plants differs from that of onshore-wind plants in fundamental aspects. The depth of water will determine if the plant choice will be Monopile, Jacket, Gravity and Tripile. Most developments will be installed on either gravity foundations or sited on steel monopiles. Gravity foundations are concrete structures which settle and are stabilised by sand or water and the turbine tower fits into them. Monopiles are long, steel tubes which are hammered, drilled or vibrated into the seabed until secure and then platforms and towers are installed on top. Another form of installation is the floating offshore wind turbines. A requirement for deep-water floating offshore wind turbines is the development of reliable, viable floatingplatform support structures. On location, the individual components of the offshore wind energy plant are erected on the plinth of the installed foundation structure and are put together to a complete plant. With the help of a crane of an erection ship or an erection platform (jack-up platforms), the first tower segment is put on top and solidly connected with the foundation through a steel flange. Following erection, wind farms have to be connected to the grid, which requires internal parking cabling as well as the external grid connection to the mainland. The transformer station of the wind farms is usually connected to a bigger transformer platform of the transmission system operator. Bigger ships are, however, needed with the cabling of the transformer stations than with the 
cable work within the wind farm. The transformer station is again connected to the grid onshore via a respective grid connection point.

Several factors can turn the process of offshore wind installation into a challenge. These factors include - offshore site conditions, technical limitations, type of vessels sea and weather conditions, etc. According to Scottish Enterprise (2010), very tight installation specifications are required by turbine suppliers, or turbine design warranties are breached. Delays are costly as hired vessels are expensive. Being unable to work yearround is a problem that affects these projects, which generally need to adopt multiseason installation schedules. Before the installation of the first turbine, prototype blades and other critical components are extreme-load tested. Typically, the prototype turbine is the subject of a series of Type tests relating to power performance, noise, grid compatibility and mechanically load measurement. Installation of the prototype turbine will be followed by installation of a small number of demonstration turbines at onshore and offshore sites. After that, the initial product maintenance phase starts with the technicians inspecting and repairing the turbine foundations and sub-sea structures. Then the technicians need to inspect and repair the subsea cables that connect the turbines to create a unified power plant. This is followed by inspection and repair of the connection of the offshore power plant to the onshore power transmission system, including onshore and offshore electrical substations and export cables. Finally, technicians need to inspect and repair the wind turbines. All of these constitute the O\&M equipment maintenance activity.

A research by the Clean Energy Pipeline on the potential for costs reductions and efficiencies in the offshore wind supply chain in Europe based on survey of 200 senior executives in the European offshore wind sector in 2014 showed that the costs of developing and constructing offshore wind farms to fall to 2.8 million per MW for projects that reach a final investment decision (FID) in 2018 and £2.4 million per MN for projects reaching a FID in 2023. Declining costs of wind farm installation will drive this improvement as foundations, and turbine towers are expected to fall by $6.6 \%, 6.1 \%$ and $5.4 \%$ respectively in the next five years" (Clean Energy Pipeline, 2014). Typically, wind turbines come with five years warranties from the manufactures following installations. In the next few years, many of the guarantees for Round One of wind farms and the early Round Two will be coming to an end in the UK. As warranties approach expiry, any inherent financial risk will rest with the owners, making efficient O\&M planning critical (NewEnergy Update, 2014). Following installations, wind turbines experience some malfunction or failure at some point in its life-cycle. Wind farm turbines have a total lifespan of between 20-25 years but suffer technical failures that reduce their availability to produce electricity. Availability is used to describe the proportion of time that a turbine, or wind farm as a whole, is technically capable of generating electricity. The maintenance element of the O\&M function involves routine and non-routine tasks, services and repairs that take place throughout the lifespan of the wind farm project. This accounts for the largest portion of O\&M cost and risks. Initially, the maintenance 
costs of a new turbine will be meagre but as the turbine ages and depending on the weather condition over the years, these operations will increase.

The estimates of the overall cost of energy of an offshore wind project are in the region of $£ 150 / \mathrm{MWh}$ and installation, and O\&M costs make up a significant portion of this cost and approximately 11 percent of the cost of an offshore wind project is associated with installation work and another 19 percent with the O\&M costs (Scottish Enterprise, 2010: 2). As shown in Figure 1, to improve availability and mitigate for failures, offshore wind turbines are subject to 'preventative' (scheduled) maintenance to mitigate potential failures and 'corrective' (unscheduled) maintenance when they fail unrepentantly. According to Hassan (2014:2) maintenance activity is the upkeep and repair of physical plant and systems and can be divided into preventative (scheduled) and corrective (unscheduled) maintenance:

- Preventative maintenance includes proactive repairs to, or replacement of, known wear components based on routine inspections or information from condition monitoring systems. It also includes regular surveys and investigations.

- Corrective maintenance includes the reactive repair or replacement of failed or damaged components. It may also be performed in a batch context when serial defects or other problems that affect a large number of wind turbines need to be corrected.

Accessing and maintaining OWF can be a costly task comparative to onshore maintenance due to the costs of hiring maintenance vessels, trained staff, marinised components etc. (Crown Estate, 2013). Therefore, limiting the number of scheduled/unscheduled maintenance visits is critical in reducing the OM cost and maximising profit which after health and safety concerns is the most vital consideration for OWF owners. In the interests of lowering maintenance visits, there is a dynamic equilibrium between maximising the extent of component maintenance during scheduled visits (to reduce costlier unplanned visits and reduced availability) at an acceptable cost. This is accomplished through condition monitoring of components, various levels of component redundancy, cycling components and basing planned maintenance on models of component failure (Li et al., 2016). This will all be codified in a maintenance master plan that is unique for each offshore project and is a function of its various elements (choice of the turbine, accessibility, user preference etc.). These master plans are dynamic and change based upon technological and strategy improvements.

There is an excellent opportunity for small to medium components to be stored, managed and mobilised from local ports by independent contractors once the maintenance contract is outsourced (dependent on O\&M Strategy). The supply chain supporting O\&M is a substantial one, and the benefits accruing to local industry is significant. Large components, heavy equipment, high-value components (blades, 
gearboxes) need a replacement that requires detailed planning and operations. An efficient transport system is required to mobilised plants and equipment from factories or central depots to ports and the offshore wind projects with active supply chain network. The closer an O\&M facility is to the offshore wind project the better to minimise travel distance. The proximity of the offshore projects from the onshore location is one of the most influential factors in the cost of offshore wind O\&M (Crown Estate, 2013). As offshore wind farms move further out to further in the deeper sea, the typical strategy employed to operate and maintain wind projects will begin to shift from a plan designed for near-shore locations. This strategy sees the crew and spares being housed in a specially constructed offshore base which is then ferried to individual turbines to conduct activities as required. The stations themselves could either be floating motherships served by smaller crew transfers, daughter, vessels or accommodation/workshop blocks cited on monopile or jacketed foundations (similar to the oil and gas industry). This Mothership approach to this strategy uses a sizeable main vessel that houses all the work technicians and crew needed for OM activities as well as the small parts and components required for scheduled and for the majority of unscheduled maintenance.

These motherships come complete with workboats to transfer crew to the offshore plants as well as accommodation and stores and can stay at sea for periods of up to two weeks. Access to turbines can be achieved by daughter craft and heavecompensated access systems (such as Ampelmann or OAS), which can operate in high sea states. Such floating, offshore-based strategies can maximise the time available for plant maintenance by reducing transit time to turbines and enabling access in severe sea states. An excellent example of this is the Fred Olsen united mothership design that houses up to forty technicians as well as four workboats. Means of gaining access to offshore turbines currently being used are workboats and helicopters services. Hassan (2013:11) describes these two main services as: "Workboats are relatively inexpensive and carry significant numbers of technicians, but transit time and sea state limits response times and accessibility. Helicopters, by comparison, are relatively expensive and cannot carry more than a few technicians and very short transit times and can operate without regard to the sea conditions (although poor visibility can impact accessibility)".

\section{Maintenance strategies}

As shown in Figure 1, the requirement for 'preventive' (scheduled) and 'corrective' (unscheduled maintenance) depend mainly on the foundation, which on its own is a function of water depth. Therefore, the depth of water will determine if the plant choice will be Monopile, Jacket, Gravity and Tripile. Offshore wind operators typically have four vessel options to maintain their plants: using the current influx of construction vessels; service vessels; helicopter transfers; or mothership type of vessels. Each, however, comes with a set of technical and financial drawbacks. Corrective maintenance becomes responsive basis when a wind turbine or other system fails. Most of the corrective events or breakdowns of turbines occur during bad weather or sea conditions, 
in strong winds, meaning that every $1 \%$ of loss in availability could mean a significantly higher loss in production. Breakdowns could lead to about one per cent loss in availability, which could mean a substantially higher loss in energy production (WWEA, 2014). To minimise the significant decline in energy production, OWF operators put in place contingencies to respond to prompt assessment, coordination and supervision of the task. This is achieved through effective remote monitoring, timely availability and access of crew, vessels and helicopters (depending on the distance to the shore, weather and sea conditions). For any given scheduled maintenance operation or failure repair, there is a chance that harsh weather will render the site inaccessible or the operation unsafe to attempt or complete (Dowell et al. 2014).

Apart from general day-to-day monitoring, each turbine is serviced annually. The number of visits required for annual 'preventive' and maintenance operations and labour requirement will vary depending on the tasks. One of the challenges facing the operators of wind farms as they move from land-based to offshore is the year-round inspection and maintenance of the turbines and underwater components. The vessel requirement will vary depending on the task, but in most cases, Crew Transfer Vessel (CTV) will be deployed. The maintenance task will require consumables, replacement parts, greases and filters. During inspections, scheduled and unscheduled operations, Remotely Operated Vehicle (ROV) will be required for cable surveys, reburying \& repairing cables, mattressing/scour prevention, BARGE will be needed for foundation/access maintenance activity. To undertake maintenance in the deep waters, Diving Equipment is required. ROV Systems describes the vehicles as "unoccupied, highly manoeuvrable, underwater robots operated by a person on the surface" (WindPower Offshore, 2014). ROV operations for marine tasks are expanding dramatically, and the demand is growing because of the vital role it plays in the offshore wind $O \& M$ and marine sector. ROVs are widely used for activities that include visual inspection of structures, scour monitoring, cable touchdown-point monitoring, debris clearance, mattress installation and retrofitting anodes and measuring cathodic potential. Also, any work involving linear structures such as cables and cable routes moving away from a vessel, and where inspection is required.

'Availability' is a measure of how little electricity is lost due to equipment downtime or failure. Findings show that 'availability' is vital to operators, turbine and parts manufacturers. For operators, the implication will be running projects at a loss or be selling power at a diminished value, thereby taking a financial hit. To ensure that plants are technically capable of producing electricity, the manufacturer provides warranty for turbines. But once this warranty period is over, when real maintenance is necessary. Maximum response times for diagnosis and repair must be stipulated in the service contract. Reliability of machinery at the end of the five years on servicing alone, while performing condition-based maintenance, means that when the warranty and service period ends, there is a high likelihood of the next stage quickly becoming very expensive (Hashem, 2013). Because the minimum has been carried out over the warranty period, significant and costly components will start to break down and need replacement - the 
kind of parts that cannot be changed out from the "bump and jump" boats, since they are service and not maintenance boats. The Crown Estate (2013) report state that technical developments expected to come forward will focus on:

- Improved remote monitoring and control to better understand the offshore plant and make previously unscheduled activities more predictable, reducing the logistical burden of putting technicians on turbines.

- Design and manufacturing improvements aimed at boosting reliability, thereby reducing the frequency and cost of unscheduled maintenance.

- Other, more fundamental, improvements such as the development of more reliable, gearless (direct drive) turbines (Hassan, 2013: 10).

\section{Operations and Supply Chain Management}

The offshore wind supply chain is evolving rapidly. This is mainly due to ambitious programmes and financial incentives that limit risk and, thus, attract investors to the sector (Athanasia, Anne-Bénédicte and Jacopo, 2012). One of the essential attributes of offshore wind is that turbines on the sea are less obtrusive and wind speeds tend to be faster than on land (American Geosciences Institute, 2018). Offshore projects generate more electricity than onshore because water has less surface roughness than land (especially deeper water), subsequently, the average wind speed is usually considerably higher over open water, leading to higher energy productivity. Transporting large wind turbine components (tower sections, nacelles, and blades) is much more accessible over water than land because ships and barges can handle large loads more efficiently than trucks or trains. Also, turbine components (rotor blades, tower sections) can be transported by barge, making large parts easier to carry offshore. Whereas the road network deficiencies and required clearances limit the size of turbine components that can be moved by truck; no such limitation exists for transport on open water. Similarly, giant construction cranes are difficult to move to remote wind farms on land, but crane vessels move easier over the sea.

As the wind farms move further into the deeper sea, O\&M costs account for 14 percent - 30 percent of total OWF lifecycle expenditure as indicated in many studies (for example, Martin et al., 2016). More so, O\&M activity accounts for approximately onequarter of the lifetime cost of an offshore wind farm and over the next two decades this industry will become a significant industrial sector in its own right (Hassan, 2013). This sector includes activities that lead to the high-level coordination and management such as monitoring, environmental monitoring, electricity sales, and marketing, administrative and other auxiliary services (as shown in Figure 1). Some of these systems in practice include Innovation Installation Vessels (IIVs), Remote Monitoring System (RMS), Remotely Operated Vehicle (ROV), etc. The Scottish Enterprise (2010) Offshore Wind 
Operations \& Maintenance, A National Renewables Infrastructure Plan Stage 2 report identified seven O\&M supply chain category as:

- Specialist consultants/architect/planning teams - required to deliver the project build from concept to completion.

- Turbine manufacturer - with initial project 5- year warranty.

- Vessel charter - ideally the developer will want a dedicated crew as part of this charter to run the vessels during the contract period. This crew will form part of the overall developer team.

- Helicopter charter - vessel charter and a dedicated crew team.

- Security and facilities management - providing O\&M support services.

- Survey teams - specialist underwater survey teams and temporary vessel charters.

- Training - the local workforce and will require a period of training.

Several studies have proved that the costs of building and maintaining wind turbines in greater depth conditions are significantly higher than those in more tranquil waters, especially when you consider the cost of cabling and connection to the central electricity system onshore. Studies such as the European Commission (2008) and BirdLife International (2009) all point to the benefits of offshore wind over the onshore farm. According to BirdLife International, (2009), offshore wind farms have many advantages over the terrestrial counterparts. First, winds at sea tend to be stronger and more consistent, and weighty turbine components are more easily transported at sea permitting more massive turbines to be constructed. Second, offshore wind farms typically encounter less resistance from local communities". Despite these benefits, this industry faces challenges ahead, as more offshore wind projects are commissioned further from shore. The Clean energy pipeline (2014) suggest that the offshore wind farm industry faces two significant challenges - policy uncertainty and the need for cost reductions.

\section{Conclusion, Contributions and Implications}

Engaging with stakeholders to drive environmental innovation requires all levels of capabilities. Innovation for ecological sustainability requires firms to engage with external stakeholders to access expertise, solve complex problems, and gain social legitimacy (Watson et al., 2018). The promotion of ORE is mainly driven by the policy to reduce dependence on conventional fossil energy resources, need to reduce the environmentally harmful Co2 emissions and to create clusters of businesses with employment generating opportunities. A significant economic growth incentive in the 
last ten years has been to install sizeable offshore wind farms. The substantial expansion of offshore wind farms in many locations in the UK is quickly developing a significant stakeholder in the offshore arena. More so, the ORE sector offers an opportunity for economic of scale of ORE and many companies are forming alliances to take advantage of the platform provided by the UK government and major investors and developers (e.g., ORSTED, E. ON, SSE Renewables, etc.) to expand and grow offshore wind farms in the UK. The government target is to create an environment where Industry and Government work together to build a competitive and innovative supply chain that delivers and sustains jobs, exports and economic benefits for the UK. The UK is currently the leader in the ORE market, and stakeholders are exploiting and developing innovative technology to protect their investment, be successful in the short and longrun. The landmark success of ORE in the UK is the result of a healthy, vibrant supply chain built with companies such as 3sun, Cwind, Seajacks, Fred Olsen Wind-carrier, etc. (RenewableUK, 2017).

Environmental sustainability and innovation require collaboration among functions such as marketing, R\&D/innovation, operations, and sustainability/corporate responsibility (Watson et al., 2018). Operational efficiencies and 'energy availability' are significant to operators, turbine and parts manufacturers due to the implications such as projects loss or selling power at a diminished value. The offshore wind companies have shown that stakeholder relationships can deliver innovative "win-win" solutions (Eccles, loannou and Serafeim, 2014). By innovating products, services, installations, operations and maintenance activities and supply chain management, offshore companies are generating environmental, economic and social value, thus legitimising their role in the economy and society. Despite the benefits of ORE over on-shore, Wind farms have a total lifespan of between 20-25 years and suffer technical failures that reduce their availability to produce electricity beyond the lifespan. Moreover, O\&M costs account for up to one-third of total OWF project lifecycle expenditure as indicated in many studies (Martin et al., 2016). To improve availability and mitigate failures, offshore wind turbines are subject to 'preventative' (scheduled) maintenance to mitigate potential failures and 'corrective' (unscheduled) maintenance activities. Management of the O\&M activities, equipment design, logistics, ports, supply chain and transportation are the right place to drive efficiency and innovation. Other activities include - sea condition monitoring, environmental monitoring, electricity sales, and marketing, administrative and other auxiliary services. These opportunities are creating a hub of large, medium and small industries (such as wind farm owners, developers, manufacturers, surveyors, specialist and professional services, and various engineering, monitoring, electrical and manufacturing industries), each creating regional job opportunities.

To conclude, the limitations of this study is related to the over-reliance on secondary data. Despite its shortcoming, this has provided the opportunity to respond to call calls for better understanding about how firms can effectively integrate stakeholder perspectives into their innovation processes, particularly in the context of environmental innovation (Watson et al., 2018). ORE companies engage in radical innovation to 
provide clean energy, reduce costs and be profitable. Platforms have been described as products or services that function as foundations upon which others and the UK government and other major stakeholders have provided the platform for entrepreneurship and clusters to develop in many offshore wind farms locations. By exploring these contexts, this article contributes to the literature on micro-foundations of innovation system and research that focuses on environmental and social goals (Govindan et al., 2015) and respond to the call to look at the institutional theory to increase understanding of how dynamic capabilities develop (Schilke, 2014). There has been calls from several scholars (e.g., Geels, Berkhout, van Vuuren, 2016; Miller, Richter and O'Leary, 2015; Nance and Boettcher, 2017) for a rethink on how to analyse implementation processes of sustainable energy transformations and the need to consider carefully the crucial characteristic of sustainable energy transformations and their embeddedness in socio-institutional processes beyond techno-economic ones (Meadowcroft, 2011; Fraune and Knodt, 2018). Therefore, there is an opportunity to advance research on how strategic resources and relational capabilities are adopted in the offshore wind supply chain and O\&M activities.

\section{Reference}

Adams, R.; Jeanrenaud, S.; Bessant, J.; Denyer, D.; Overy, P. (2016), Sustainability-oriented Innovation: A Systematic Review. Int. J. Manag. Review, 18, 180-205.

Athanasia, A., Anne-Bénédicte G. and Jacopo, M. (2012), The offshore wind market deployment: forecasts for 2020, 2030 and impacts on the European supply chain development. Energy Procedia 24: 2 - 10

Anvuur, A. M. and Kumaraswamy, M. M. (2007), Conceptual model of partnering and alliancing. Journal of Construction Engineering and Management, 133(3), 225-234. DOI: 10.1061/(ASCE)07339364(2007) file:///C:/Users/user/Downloads/Conceptual Model of Partnering and Alliancing.pdf

American Geosciences Institute (2018), What are the advantages and disadvantages of offshore wind farms? https://www.americangeosciences.org/critical-issues/faq/what-are-advantages-anddisadvantages-offshore-wind-farms Accessed 10/07/2018

Bessant, J., Ramalingam, B., Rush, H., Marshall, N., Hoffman, K. and Gray, B. (2014), Innovation Management, Innovation Ecosystems and Humanitarian Innovation. Literature Review for the Humanitarian Innovation Ecosystem Research Project, June 2014. Accessed 15/07/2108 file://C:/Users/user/Downloads/dfid lit review final 0.pdf

Bilgili, M., Yasar, A. and Simsek, E. (2011), Offshore wind power development in Europe and its comparison with onshore counterpart. Renewable Sustainable Energy Review, 15(2): 905-915. 
BirdLife International (2009), Offshore wind farms are impacting seabirds and migrating passerines. Presented as part of the BirdLife State of the world's birds website. Available from: http://www.birdlife.org/datazone/sowb/casestudy/289 . Accessed: 22/04/2015

Bogers, M., Zobel, A-K., Afuah, A., Almirall, E., Brunswicker, S., Dahlander, L., Frederiksen, L., Gawer, A., Gruber, M. and Haefliger, S. (2017), The open innovation research landscape: Established perspectives and emerging themes across different levels of analysis. Industry and Innovation, 24(1): 8-40.

Brown, J. S. and Duguid, P. (1991), Organizational Learning and Communities-of Practice: Toward a Unified View of Working, Learning, and Innovating. Organization Science, 2 (1): 40.

Catapult (2018), New Competition puts UK SMEs in investor spotlight. https://ore.catapult.org.uk/pressreleases/new-offshore-wind-innovation-competition-puts-uk-smes-in-investor-spotlight/

Chaminade, C., Intarakumnerd, P, and Sapprasert, K. (2012), Measuring systemic problems in National Innovation Systems: an application to Thailand. Research Policy, 41, 1476-1488.

Colombo, M. G., von Krogh, G., Rossi-Lamastra, C. and Stephan, P. E. (2017), Organizing for Radical Innovation: Exploring Novel Insights. J. Prod. Innov. Manag., 34: 394-405. doi:10.1111/jpim.12391

Copena, D. and Simon, X. (2018), Wind farms and payments to landowners: Opportunities for rural development for the case of Galicia. Renewable and Sustainable Energy Reviews, Vol. 95: 38-47

Corral, M. C. (2002), Environmental Policy and Technological Innovation: Why Do Firms Adopt or Reject New Technologies? New Horizons in the Economics of Innovation series. Institute of Strategy, Technology and Policy, TNO, Netherlands Organisation for Applied Scientific Research, Delft, The Netherlands. ISBN: 9781840649574 Edward Elgar Publishing

Crown Estate (2013), A Guide to UK Offshore Wind Operations and Maintenance. file://C:/Users/user/Downloads/Offshore-wind-guide-June-2013.pdf

Danilova, J., Grant, D. B. and Menachof, D. (2016), Investigating SMEs participation in the UK offshore wind supply chain. Hull University Business School, UK, Hanken School of Economics, Finland, The University of Hull's Knowledge Exchange/HEIF funding and the University's Centre for Adaptive Science and Sustainability report. https://hydra.hull.ac.uk/assets/hull:14069/content

Dedecca, J. G., Hakvoort, R. A. and Ortt, J. R. (2016). Market strategies for offshore wind in Europe: A development and diffusion perspective. Renewable \& Sustainable Energy Reviews, Vol. 66: 286296

Dowell, J., Zitrou, A., Walls, L., Bedford, T. and Infield, D. (2014), Analysis of Wind and Wave Data to Assess Maintenance Access to Offshore Wind Farms http://www.strath.ac.uk/media/departments/eee/iee/windenergydtc/publications/Dowell2013b.pdf 
Dyer, J. H. and Singh, H. (1998), "The relational view: cooperative strategy and sources of interorganizational competitive advantage". Academy of Management Review, Vol. 23 No. 4, pp. 660679.

Eccles, R. G., Ioannou, I. and Serafeim, G. (2014), The impact of corporate sustainability on organizational processes and performance. Management Science, 60: 2835-57.

Eckhardt, J. T., Ciuchta, M. P. and Carpenter, M. (2018), Open Innovation, Information, and Entrepreneurship within Platform Ecosystems, Strategic Entrepreneurship Journal doi: 10.1002/sej.1298

Ernst \& Young (2013), Renewable Energy Country Attractiveness Indices http://www.ey.com/Publication/vwLUAssets/RenewableenergycountryattractivenessindicesIssue37/\$FILE/RECAI-May-2013.pdf

Estay, C., Durrieu, F. and Akhter, M. (2013), "Entrepreneurship: from motivation to start-up". Journal of International Entrepreneurship, Vol. 11 No. 3, pp. 243-267.

Etzkowitz, H. (2003). Innovation in innovation: The Triple Helix of university-industry-government relation'. Social Science Information, 42(3): 293-338.

Etzkowitz, H. and Leydesdorff, L. (2000), The dynamics of innovation: From National Systems and 'Mode 2' to a Triple Helix of university-industry-government relations, Research Policy, Vol. 29 No. 2, pp. 109-123.

European Commission (2008), Offshore wind energy: action needed to deliver on the energy policy objectives for 2020 and beyond. Communication from the Commission to the European Parliament, the Council, the European Economic and Social Committee and the Committee of the Regions, Brussels

European Commission Committee of Regions (2016). Using the Quadruple Helix Approach to Accelerate the Transfer of Research and Innovation Results to Regional Growth. The European Union. pp. 1- 165 https://cor.europa.eu/en/engage/studies/Documents/quadruple-helix.pdf

EWEA (2015) The European offshore wind industry - key trends and statistics 2014. http://www.ewea.org/fileadmin/files/library/publications/statistics/EWEA-European-Offshore-Statistics2014.pdf

Fischer, B. B., Queiroz, S. and Vonortas, N. S. (2018), On the location of knowledge-intensive entrepreneurship in developing countries: lessons from São Paulo, Brazil. Entrepreneurship \& Regional Development, 30:5-6, 612-638, DOI: 10.1080/08985626.2018.1438523

Fraune, C. and Knodt, M. (2018), Sustainable energy transformations in an age of populism, post-truth politics, and local resistance. Energy Research \& Social Science, Available online 31 May 2018 https://doi.org/10.1016/j.erss.2018.05.029 
Gawer, A. (2010), The organization of technological platforms, in Nelson Phillips, Graham Sewell, Dorothy Griffiths (ed.) Technology and Organization: Essays in Honour of Joan Woodward (Research in the Sociology of Organizations, Vol. 29. Emerald Group Publishing Limited, pp. 287 $-296$

Geels, F. W., Berkhout, F., van Vuuren, D. P. (2016), Bridging analytical approaches for low-carbon transitions. Nature Climate change, 6(6): 576-83.

Geerts, A., Leten, B., Belderbos, R. and Looy, B. V. (2018), Does Spatial Ambidexterity Pay Off? On the Benefits of Geographic Proximity Between Technology Exploitation and Exploration. Journal of Production Innovation Management, 35(2):151-163

Govindan, K., Soleimani, H. and Kannan, D. (2015), "Reverse logistics and closed-loop supply chain: A comprehensive review to explore the future", European Journal of Operational Research, Vol. 240(3): 603-626.

Guan, J. and Chen, K. (2012), Modelling the relative efficiency of national innovation systems. Research Policy, 41, 102-115

Hassan, GL. G. (2013), A Guide to UK Offshore Wind Operations and Maintenance', Scottish Enterprise and the Crown Estate. file:///C:/Users/user/Downloads/Offshore-wind-guide-June2013.pdf

Hart, S. L. (1995), A natural-resource-based view of the firm. The Academy of Management Review, 20(4): 986-1014.

Hart, S.L. and Dowell, G. (2011), "A natural-resource-based view of the firm: Fifteen years after", Journal of Management, Vol. 37(5), pp.1464-1479.

Henisz, W. J., Dorobantu, S. and Nartey, L. J. (2014), Spinning gold: The financial returns to stakeholder engagement. Strategic Management Journal, 35: 1727-48.

HM Government (2013), Offshore Wind Industrial Strategy Business and Government Action. Industrial Strategy: government and industry in partnership. https://assets.publishing.service.gov.uk/government/uploads/system/uploads/attachment data/fil e/243987/bis-13-1092-offshore-wind-industrial-strategy.pdf

lansiti, M. and Levien, R. (2004), The keystone advantage: what the new dynamics of business ecosystems mean for strategy, innovation, and sustainability. Harvard Business Press.

Igwe, P. A. and Howell, K. E. (2015), The UK offshore wind job creation capacity, O\&M costs and content analysis: Design \& Operation of Wind Farm Support Vessels Conference, 28-29 January 2015, London. http://www.rina.org.uk/Wind Farm 2015 Papers.html

Kanter, R. M. (1994). Collaborative advantage. Harvard Business Review, 72(4), pp.96-108. 
Kemp, R. and P. Pearson. (2008), Final Report MEI project about measuring eco-innovation. Available at: http://www.oecd.org/env/consumption-innovation/43960830.pdf

Krikke, H., Hofenk, D. and Wang, Y. (2013), Revealing an invisible giant: A comprehensive survey into return practices within original (closed-loop) supply chains, Resources, Conservation and Recycling, Vol.73, pp.239-250.

Leppäaho, T. and Pajunen, K. (2018). Institutional distance and international networking. Entrepreneurship \& Regional Development, 30:5-6, 502529, DOI: $\underline{10.1080 / 08985626.2017 .1407365}$

Leven, P., Holmstrom, J., and Mathiassen, L. (2014), Managing research and innovation networks: evidence from a government sponsored cross-industry program. Research Policy, 43, 156-168.

Li, X., Ouelhadj, D., Song, X., Jones, D., Wall, G., Howell, K. E., Igwe, P. A., Martin, S. Song, D. and Pertin, E. (2015a), WP1report: Maintenance Decision Support Tool, 2OM Project, 2015.

Li, X., Ouelhadj, D., Song, X., Jones, D., Wall, G., Howell, K. E., Igwe, P. A., Martin, S. Song, D. and Pertin, E. (2015b), WP4 Report: Communication, 2OM Project, 2015.

Li, X., Ouelhadj, D., Song, X., Jones, D., Wall, G., Howell, K. E., Igwe, P. A., Martin, S. Song, D. and Pertin, E. (2016). A decision support system for strategic maintenance planning in offshore wind farms. Renewable Energy, 99, 784 - 799

Malik, T. H. (2013), National institutional differences and cross-border university-industry knowledge transfer. Research Policy, 42, 776-787.

Matopoulos, A., Barros, A. C. and van der Vorst, J. G. (2015), "Resource-efficient supply chains: a research framework, literature review and research agenda", Supply Chain Management: An International Journal, Vol.20 No.2, pp.218-236.

Matos, S. and Hall, J. (2007), Integrating sustainable development in the supply chain: The case of life cycle assessment in oil and gas and agricultural biotechnology, Journal of Operations Management Vol.25 No.6, pp.1083-1102.

Martin, R., Lazakis, I., Barbouchi, S. and Johanning, L. (2016), Sensitivity analysis of offshore wind farm operation and maintenance cost and availability. Renewable Energy, 85: 1226-1236

McDermott, G. A. and Corredoira, R. A. (2010), Network composition, collaborative ties, and upgrading in emerging-market firms: Lessons from the Argentine auto-parts sector. Journal of International Business Studies, 41(2): 308-329.

McLure, M. and Faraj, S. (2000), "It is what one does: why people participate and help others in electronic communities of practice". The Journal of Strategic Information Systems, Vol. 9 No. 2 , pp. $155-173$ 
McLure-Wasko, M. and Faraj, S. (2005), "Why should I share? Examining social capital and knowledge contribution". MIS Quarterly, Vol. 29 No. 1, pp. 35-37

Meadowcroft J. (2011), Engaging with the politics of sustainability transitions. Environmental Innovation and Societal Transitions, 1(1):70-5.

Miemczyk, J., Howard, M. and Johnsen, T. E. (2016), Dynamic development and execution of closedloop supply chains: a natural resource-based view", Supply Chain Management: An International Journal, Vol. 21(4): 453 - 469 http://dx.doi.org/10.1108/SCM-12-2014-0405

Miller, C. A., Richter, J., O’Leary, J. (2015), Socio-energy systems design: A policy framework for energy transitions. Energy Research \& Social Science, 6:29-40.

Morris, M., Kaplinsky, R. and Kaplan, D. (2012), One thing leads to another" - Commodities, linkages and industrial development. Resources Policy, 37(4): 408-416.

Mudambi, R., Narula, R. and Santangelo, G. (2017), Location, collocation and innovation by multinational enterprises: a research agenda. Industry and Innovation, 25(3): 229-241.

Nance, M. T., Boettcher, W. A. (2017), Conflict, cooperation, and change in the politics of energy interdependence: An introduction. Energy Research \& Social Science, 24:1-5.

Narula, R. (2014). Exploring the paradox of competence-creating subsidiaries: Balancing bandwidth and dispersion in MNEs. Long Range Planning, 47(1-2): 4-15.

NewEnergyUpdate (2014). When offshore warranties expire. http://newenergyupdate.com/wind-energyupdate/when-offshore-warranties-expire Accessed: 12/06/2015

OECD (2000). Sustainable Innovation: Drivers and Barriers. World Business Council for Sustainable Development. Dearing/OECD TIP workshop 19.06.2000, 4 chemin de Conches 1231 Geneva. https://www.oecd.org/innovation/inno/2105727.pdf

Organization for Economic Co-operation and Development, OECD. 2016. Entrepreneurship at a Glance. OECD Publishing, Paris. http://dx.doi.org/10.1787/entrepreneur aag-2016-en Accessed: 10/12/2017

OffshoreWind.biz, (2016). UK Funding Innovative Offshore Wind Cost Reduction Projects. https://www.windpoweroffshore.com/article/1314300/making-right-subsea-skills-choice Accessed: 16/05/2018.

Offshore wind Cost Reduction Task Force (CRTF, 2012). https://assets.publishing.service.gov.uk/government/uploads/system/uploads/attachment data/fil e/66776/5584-offshore-wind-cost-reduction-task-force-report.pdf 
Ornelia, W. M. (2015), Determinants of university-firm R\&D collaboration and its impact on innovation: a perspective from a low-tech industry. Research Policy, 44:1341-1359.

O'Riordan, L. and Fairbrass, J. (2014), Managing CSR Stakeholder engagement: A new conceptual framework. Journal of Business Ethics, 125 (1): 121-45.

Owen-Smith, J., \& Powell, W. (2004), Knowledge networks as channels and conduits: The effects of spillovers in the Boston biotechnology community. Organization Science, 15(1): 5-21.

Patel, P. and Pavitt, K. (1994), "The Nature and Economic Importance of National Innovation Systems", STI Review, No. 14, OECD, Paris.

Perkmann, M. and Walsh, K. (2007), University-industry relationships and open innovation: Towards a research agenda. International Journal of Management Reviews, 9(4): 259-280.

Perkmann, M. and Schildt, H. (2015), Open data partnerships between firms and universities: the role of boundary organizations. Research Policy, 44, 1133-1143.

Poulsen, T. and Lema, R. (2017), Is the supply chain ready for the green transformation? The case of offshore wind logistics. Renewable and Sustainable Energy Reviews, Vol. 73: 758-771

Powell, W. W., Koput, K. W., and Smith-Doerr, L. (1996), Interorganizational collaboration and the locus of innovation: Networks of learning in biotechnology. Administrative Science Quarterly, 41(1), 116-145.

Rahman, S. and Subramanian, N. (2012), Factors for implementing end-of-life computer recycling operations in reverse supply chains", International Journal of Production Economics, Vol.140 No.1, pp.239-248.

Ratten, V. (2014), Encouraging collaborative entrepreneurship in developing countries: The current challenges and a research agenda, Journal of Entrepreneurship in Emerging Economics, 6(3), 298- 308

Razak, A. A. and White, G. R. T. (2015), The Triple Helix Model for Innovation: a holistic exploration of barriers and enablers. International Journal of Business Performance and Supply Chain Modelling, 7(3), 278-291.

RenewableUK (2017), Offshore Wind Regenerating Regions - Investment and Innovation in the UK. https://c.ymcdn.com/sites/renewableuk.siteym.com/resource/resmgr/Offshore Wind Week 2017 repo.pdf Accessed: 06/06/2018

RenewableUK (2018), New wind energy record set - during another British cold snap. http://www.renewableuk.com/news/391498/New-wind-energy-record-set---during-another-Britishcold-snap-.htm Accessed: 5/06/2018 
Rypestøl J. O. and Aarstad, J. (2018), Entrepreneurial innovativeness and growth ambitions in thick vs. thin regional innovation systems. Entrepreneurship \& Regional Development, 30:5-6, 639661, DOI: $\underline{10.1080 / 08985626.2018 .1444104}$

Scarmozzino, E. Corvello, V. and Grimaldi, M. (2017), Entrepreneurial learning through online social networking in high-tech startups, International Journal of Entrepreneurial Behavior \& Research, Vol. 23 Issue: 3, pp.406-425, https://doi.org/10.1108/IJEBR-12-2015-0302

Schilke, O. (2014). Second-order dynamic capabilities: How do they matter? The Academy of Management Perspectives, 28(4): 368-80.

Scottish Enterprise (2010), Offshore Wind Operations \& Maintenance, A National Renewables Infrastructure Plan Stage 2 (Highlands and Islands Enterprise), Pp. 1 - 10 http://www.hienergy.org.uk/Downloads/General\%20Documents/Operations\%20and\%20Maintena nce\%20Brochure.pdf

Scottish Enterprise (2010), Innovation in Offshore Wind, installation, operations and maintenance: http://www.scottishenterprise.com/ /media/SE/Resources/Documents/MNO/OW\%20Innovation\% 20-\%20IOM\%20v1.0.pdf downloaded 19/05/2014

Seitz, M. and Peattie, K. (2004), "Meeting the closed-loop challenge", California Management Review, Vol.46 No.2, pp.74-89.

Shi, G., Koh, L., Baldwin, J. and Cucchiella, F. (2012), "Natural resource based green supply chain management", Supply Chain Management: An International Journal, Vol.17 No.1, pp.54-67.

Vasudeva, G. and Anand, J. (2011), Unpacking Absorptive Capacity: A Study of Knowledge Utilization from Alliance Portfolios, Academy of Management Journal, 54(3): 611-623.

Watkins, A., Papaioannou, T., Mugwagwa, J. and Kale, D. (2015), National innovation systems and the intermediary role of industry associations in building institutional capacities for innovation in developing countries: a critical review of the literature. Research Policy, 44, 1407-1418.

Watson, R., Wilson, H. N., Smart, P. and Macdonald, E. K (2018), Harnessing Difference: A CapabilityBased Framework for Stakeholder Engagement in Environmental Innovation. J Prod Innovation Management, 35(2):254-27

WindPower Offshore (2014), Making the right subsea skills choice. 30 September 2014. https://www.windpoweroffshore.com/article/1314300/making-right-subsea-skills-choice Accessed: $10 / 08 / 2015$

WWEA (2014), Operation and Maintenance of Wind Farms - Introduction and Overview, Pp. 1 - 6. World Wind Energy Association http://www.wwindea.org/technology/ch03/en/3 1 1.html 
Zhao, Z. J. and Anand, J. (2009), A multilevel perspective on knowledge transfer: Evidence from the Chinese automotive industry. Strategic Management Journal, 30(9): 959-983. 